\title{
Pengembangan Nominal Aturan pada Metode Fuzzy Mamdani untuk Menyeimbangkan Beban Tiga Phasa pada Saluran Distribusi Tegangan Menengah
}

\author{
Martinus W. Djagolado ${ }^{1}$, Amirullah ${ }^{1 *}$, Saidah ${ }^{1}$
}

${ }^{1}$ Program Studi Teknik Elektro Fakultas Teknik Universitas Bhayangkara Surabaya

Jl. Ahmad Yani Frontage Road No. 114 Gayungan Kota Surabaya 60231 Jawa Timur

*amirullah@ubhara.ac.id

DOI: https://doi.org/10.21107/rekayasa.v14i3.10655

\begin{abstract}
The use of electrical equipment on the customer side with low voltage absorbs unbalanced power. The load unbalances in each phase will result in an unbalanced current, resulting in a phase voltage shift in the secondary coil of the $20 \mathrm{kV} / 380 \mathrm{~V}$ medium voltage transformer. Shifting the voltage in the distribution transformer phase, then causes the flow of current in the transformer neutral wire causing losses. This paper proposes a fuzzy logic method with the Mamdani fuzzy inference system (FIS) to balance three-phase load currents at seven feeders of $20 \mathrm{kV}$ medium voltage distribution at PLN Rayon Taman JawaTimur. The feeders are Ngelom, Tawang Sari, Geluran, Bringin, Masangan Kulon, Palm Residence, and Pasar Sepanjang. There are three input variables used, namely the load current in phase $R$, phase $S$, and phase T respectively. There are three output variables in one FIS block, namely changes in load current in phase $R$, phase $S$, and phase T respectively. With the number of fuzzy rules as many as 509 rules, the proposed method is able to produce the lowest load current unbalance value of $1.6 \%$ at Palm Residence Feeders. The development of a nominal (number) of fuzzy rules in the Fuzzy Logic Method with FIS Mamdani is able to reduce the value of unbalance load current at the $20 \mathrm{kV}$ medium voltage distribution feeder better than the method proposed by previous researchers.
\end{abstract}

Key words : load current unbalance, fuzzy-mamdani, fuzzy-rules, feeder

\section{PENDAHULUAN}

Sistem distribusi adalah bagian sistem tenaga listrik yang berperan penting dalam penyaluran energi listrik kepada pelanggan listrik tegangan menengah dan rendah. Pada sisi tegangan rendah satu phasa, sering terjadi pemakaian peralatan listrik yang menyerap daya tidak seimbang oleh konsumen. Ketidakseimbangan daya beban pada masing-masing phasa akan menghasilkan arus tidak seimbang sehingga menyebabkan pergeseran tegangan phasa pada sisi kumparan sekunder transformator tegangan menengah $20 \mathrm{kV} / 380 \mathrm{~V}$. Pergeseran tegangan pada masing-masing phasa transformator tegangan menengah selanjutnya menyebabkan aliran arus pada kawat netral transformator sehingga akhirnya menyebabkan rugi-rugi (Putu Weda et al., 2018). Standar PLN Nomor 1 Tahun 1995 menyebutkan bahwa faktor ketidakseimbangan beban minimal adalah 20 persen, sehingga jika nilai ketidakseimbangan sudah melebihi nilai tersebut maka sejumlah

\section{Article History:}

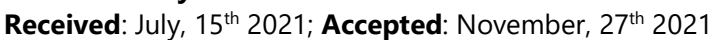

Rekayasa ISSN: 2502-5325 has been Accredited by Ristekdikti (Arjuna) Decree: No. 23/E/KPT/2019 August 8th, 2019 effective until 2023 langkah harus dilakukan oleh PLN untuk menyeimbangkan distribusi beban secara berkala.

Manajemen penggunakan transformator dengan cara mutasi transformator sudah dilakukan oleh (Sudiartha et al., 2016) untuk mengatasi beban tidak seimbang dan drop tegangan. Metode mutasi dilakukan dengan cara menukar posisi antar dua gardu transformator dengan dengan bantuan simulasi software menggunakan program ETAP. Metode mutasi transformator secara optimal mampu mengatasi pembebanan transformator berbeban rendah dan berkapasitas overload meskipun persediaan transformator cadangan relatif terbatas.

Optimalisasi pembebanan transformator distribusi tiga phasa untuk penyeimbangan beban sesuai dengan kapasitas nominal transformator dan standar PLN sudah dilakukan oleh (Gassing et al., 2013). Analisis keseimbangan beban pada

\section{Cite this as:}

Djagolado, M.W., S., Amirullah \& Saidah. (2021). Pengembangan Nominal Aturan pada Metode Fuzzy Mamdani untuk Menyeimbangkan Bebab Tiga Phasa pada saluran Distribusi Tegangan Menengah . Rekayasa 14 (3). 431-442. doi: https://doi.org/10.21107/rekayasa.v14i3.10655. 
transformator distribusi pada penyulang dilakukan melalui pengukuran beban saat waktu beban puncak dan luar beban puncak. Data-data hasil pengukuran tersebut selanjutnya dianalisis dan dioptimalisasi oleh peneliti untuk mengetahui level pembebanan transformator tiga phasa baik pada kondisi sebelum dan sesudah dilakukan penyeimbangan beban dilakukan. Analisis keseimbangan beban pada sistem distribusi dan pengaruhnya terhadap jatuh tegangan dan rugi daya sistem sudah diinvestigasi oleh (Sukmadi et. al., 2009).

Metode penyeimbangan beban dilakukan secara manual dengan cara memindahkan beban dari phasa yang mengalami beban lebih ke phasa yang bebannya kurang. Protoptipe sistem monotoring dan penyeimbang arus beban pada sistem tiga phasa menggunakan Mikrokontroler ATMega 2560 untuk mengurangi rugi daya akibat aliran arus pada kawat netral sudah diimplemantasikan oleh (Putra et al., 2017). Prototipe yang diusulkan mampu menyeimbangan beban dengan memindahkan saluran beban dari urutan beban terkecil yang tersambung ke phasa dengan beban terbesar menuju phasa yang memiliki beban terkecil ketika arus netral melebihi batas yang diinginkan.

Analisis sistem tenaga listrik akibat ketidakseimbangan beban pada setiap bus menggunakan formulasi aliran daya tiga phasa tidak seimbang sudah diobservasi oleh (Nazaruddin et. al., 2019). Penyelesaian aliran daya tiga phasa pada penelitian diterapkan pada sistem IEEE 5 bus dengan Metode Gauss-Seidel menggunakan bantuan perangkat lunak Matlab. Pengaruh ketidakseimbangan beban antar phasa pada kinerja transformator, panas berlebih pada phasa yang mengalami beban lebih, aliran arus pada kawat netral, dan drop tegangan ujung pada jaringan phasa beban lebih sudah dibahas oleh (Hidayat et. al, 2018). Pengaruh ketidakseimbangan beban terhadap arus netral dan losses pada transformator distribusi sudah diobservasi oleh (Sitepu, 2011). Hasil penelitian menunjukkan bahwa semakin besar arus netral yang mengalir pada penghantar netral transformator, maka losses penghantar juga semakin besar. Jika arus netral yang mengalir ke tanah semakin besar, maka rugi-rugi transformator juga semakin besar. Jika arus netral dan losses tranformator semakin besar, maka efisiensi transformator semakin turun turun. Investigasi pengaruh ketidakseimbangan beban terhadap rugi- rugi daya pada transformator $20 \mathrm{kV}$ dan penyulang tegangan rendah sudah dilakukan oleh (Mertasana, 2016). Hasil penelitian menujukkan bahwa semakin besar arus netral yang mengalir pada penghantar netral transformator, maka rugi-rugi pada pengantar netral transformator juga semakin besar. Peningkatan rugi-rugi pada penghantar netral selanjutnya menyebabkan penurunan effisiensi transformator.

Dampak ketidakseimbangan beban transformator terhadap rugi-rugi arus netral, kenaikan suhu minyak, dan suhu belitan sudah diobservasi oleh (Jayabadi et al., 2016). Penyeimbangan beban dilakukan dengan mengubah hubungan phasa transformator dari phasa ke phasa yang lain tanpa mengubah kapasitas beban transformator yang terhubung pada empat penyulang menggunakan perangkat lunak ETAP. Hasil penelitian menujukkan bahwa metode yang diusulkan mampu mengurangi rugirugi akibat arus pada penghantar netral, menurunkan suhu minyak, dan sekaligus menurunkan suhu belitan transformator daya.

Analisis pengaruh penyeimbangan beban transformator distribusi disuplai oleh Pembangkit Listrik Tenaga Diesel (PLTD) terhadap rugi-rugi daya dan susut energi sudah diobservasi oleh (Antonov et al., 2015). Hasil penelitian menunjukkan bahwa penyeimbangan beban transformator mampu mengurangi susut energi pada penyulang secara signifikan dari $17.270 \mathrm{kWh}$ menjadi $7.408 \mathrm{kWh}$ per bulan dan biaya bahan bakar solar dari Rp. 61,2 juta menjadi Rp. 37.7 juta per bulan. Analisis penyeimbangan beban trasformator pada Luar Waktu Beban Puncak (LWBP) dengan metode SBS (Seimbang Beban Seharian) sudah dilakukan oleh (Abdillah et al., 2014). Penelitian menghasilkan keseimbangan antar fasa pada transformator daya mampu dicapai di semua titik waktu kurva pembebanan. Dengan indikator penurunan nilai arus maksimum, arus netral rata-rata, dan nilai ratarata ketidakseimbangan beban selama sehari. Metode SBS juga sudah diimplementasikan oleh (Bahtiar et al., 2017) untuk mengu rangi losses akibat adanya arus netral mengalir pada titik netral transformator dan losses akibat arus netral mengalir ke tanah.

Dalam perkembangan selanjutnya metode logika fuzzy banyak digunakan dalam analisis keseimbangan beban pada penyulang jaringan distribusi Alasannya adalah pemodelannya relatif sederhana, tidak membutuhkan persamaan 
matematika rumit, sehingga mampu mengatasi masalah secara lebih cepat berdasarkan variabel FIS masukan dan keluaran data beban penyulang. Keunggulan logika fuzzy lain adalah mampu membangun dan mengaplikasikan pengalamanpengalaman pengguna secara langsung tanpa harus melalui proses pelatihan, dapat memodelkan fungsi-fungsi nonlinier yang sangat kompleks dan dapat bekerjasama dengan teknik-teknik kendali konvensional lainnya. Metode Logika Fuzzy dalam pengambilan keputusan untuk menentukan efisiensi kerja terbaik pada transformator distribusi sudah diaplikasikan oleh (Kahfi et al., 2017). Variable masukan fuzzy yang digunakan meliputi tegangan, arus asli, dan arus efisien dengan variabel keluarannya adalah persentase tegangan transformator yang paling efisien. Dengan menggunakan delapan aturan dasar fuzzy (fuzzy rule base), maka pengambil keputusan fuzzy (fuzzy decision making) mampu menentukan urutan transformator yang mampu bekerja secara efisien dengan nilai mean average percentage error (MAPE) sebesar $10,4 \%$. Perangkat lunak berbasis Metode Fuzzy Inferensi Tsukamoto untuk menentukan faktor pembebanan dan mendeteksi jenis gangguan pada transformator distribusi PLN sudah diimplementasikan oleh (Thamrin et al., 2012). Deteksi kerusakan transformator pada penelitian ini ditentukan oleh pembebanan, ketidakseimbangan beban, jatuh tegangan, dan faktor daya transformator.

Metode logika fuzzy sebagai evaluasi distribusi daya berdasarkan beban puncak pembangkit sudah diperkenalkan oleh (Rosalina et al., 2016). Metode Fuzzy Mamdani digunakan sebagai hasil evaluasi daya pada sistem pembangkit menggunakan tiga variabel masukan antara-lain meliputi kapasitas terpasang, kemampuan daya, dan produksi listrik serta data beban puncak sebagai variabel keluaran. Metode logika fuzzy dengan FIS Mamdani dan 8 aturan fuzzy untuk menyeimbangkan beban total per-phasa dalam kilowatt (kW) pada jaringan distribusi sekunder diinvestigasi oleh (Siti et al., 2007). Variabel masukan berjumlah tiga masingmasing arus beban pada phasa $R$, phasa $S$, dan phasa T. Sedangkan variabel keluaran berjumlah satu yaitu perubahan arus beban, masing-masing phasa $R$, phasa $S$, dan phasa T dengan 3 buah blok model FIS Mandani terpisah. Metode mendekati sama juga sudah dilakukan oleh (Patel, 2007). Pada penelitian ini, penulis mengusulkan metode logika fuzzy dengan FIS Mamdani. Serupa dengan dua penelitian terakhir, metode ini menggunakan 3 variabel masukan masing-masing arus beban pada phasa $R$, phasa $S$, dan phasa $T$. Perbedaannya adalah variabel keluaran penelitian berjumlah 3 tetapi tetap berada dalam 1 blok FIS dimana masing-masing adalah perubahan phasa $\mathrm{R}$, phasa $\mathrm{S}$, dan phasa T. Permasalahan dan metode penelitian difokuskan pada analisis menyeimbangkan arus beban penyulang tiga phasa dalam satuan ampere (A). Sumber data penelitian adalah data beban pelanggan PLN UP3 Surabaya Barat Rayon Taman Jawa-Timur.

\section{METODE PENELITIAN}

Analisis ketidakseimbangan beban di jaringan tegangan menengah dilakukan pada sejumlah penyulang yang terhubung pada transformator 150/20 kV. Penelitian dilakukan pada tanggal 25 April s/d 24 Mei 2019 di PT. PLN (Persero) UP3 Surabaya Barat Rayon Taman Sidoarjo Jawa-Timur. Penyulang $20 \mathrm{kV}$ berfungsi untuk menghubungkan gardu induk dengan gardu-gardu (transformator) distribusi hingga sampai ke gardu hubung. Untuk pelanggan-pelanggan khusus berkapasitas daya besar diatas 200 kVA terdapat trafo khusus untuk menurunkan tegangan menjadi $20 \mathrm{kV}$ dari penyulang menuju ke beban. Pada penelitian ini selanjutnya dipilih tujuh penyulang $20 \mathrm{kV}$ Area UP3 Taman yang mempunyai nilai ketidakseimbangan arus beban lebih dari $20 \%$. Penyulang-penyulang tersebut antara-lain Tawang Sari, Ngelom, Geluran, Bringin, Masangan Kulon, Palm Residence, dan Pasar Sepanjang. Pengukuran arus beban perpenyulang dilakukan pada waktu beban puncak (WBP) antara pukul 17.00-22.00 WIB. Data-data hasil pengukuran pada tujuh penyulang selanjutnya diolah menggunakan Metode Logika Fuzzy dengan FIS-Mamdani sehingga diperoleh arus beban tiga phasa mendekati kondisi seimbang sesuai dengan standar PLN sebesar $20 \%$.

Metode untuk menyeimbangkan arus beban tiga phasa menggunakan metode fuzzy mamdani ditunjukkan pada Gambar 1. Tahapan penelitian dimulai dari pengumpulan data arus beban phasa $A$, phasa $B$, dan phasa $C$ pada setiap penyulang 20 kV. Data arus beban selanjutnya menjadi variabel masukan bagi metode logika fuzzy yaitu masukan phasa $R$, masukan phasa $S$, dan masukan phasa $T$. Selanjutnya masukan data arus pada masingmasing phasa akan diproses oleh metoda logika 
fuzzy hingga menghasilkan variabel data keluaran arus. Diagram alir metode logika fuzzy ditunjukkan pada Gambar 2 yang meliputi urutan tahapan berikut: crips masukan, fuzzifikasi, fuzzy masukan, fuzzy inference system (FIS), fuzzy keluaran, defuzzifikasi, dan crips keluaran. Data keluaran variable arus beban juga berjumlah tiga masingmasing keluaran phasa $R$, keluaran phasa $S$, keluaran phasa T. Data keluaran arus beban pada masing-masing phasa selanjutnya akan diseimbangkan menggunakan persamaan matriks dan selanjutnya menghasilkan data arus beban yang sudah mendekati seimbang. Nilai ketidakseimbangan arus beban dihitung dari data arus keluaran pada setiap phasa dan selanjutnya dibandingkan dengan Standar ketidakseimbangan beban PLN. Jika nilainya masih lebih besar dari 20\%, maka nilai arus keluaran pada setiap phasa dianggap belum seimbang dan akan kembali mengalami perulangan proses dengan metode logika fuzzy. Jika nilai ketidakseimbangan arus beban sudah di bawah 20\%, maka nilai arus beban pada setiap phasa sudah seimbang.

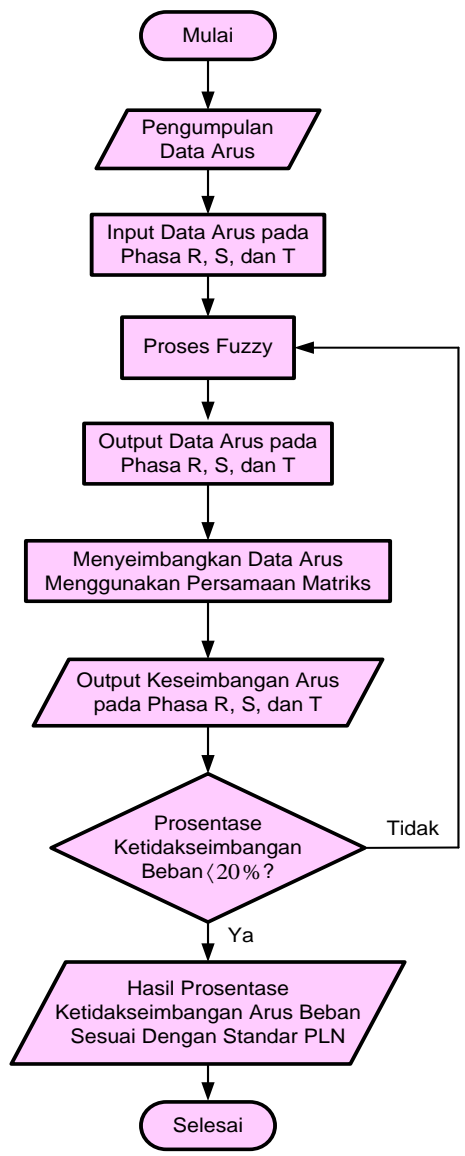

Gambar 1. Diagram Alir Penelitian

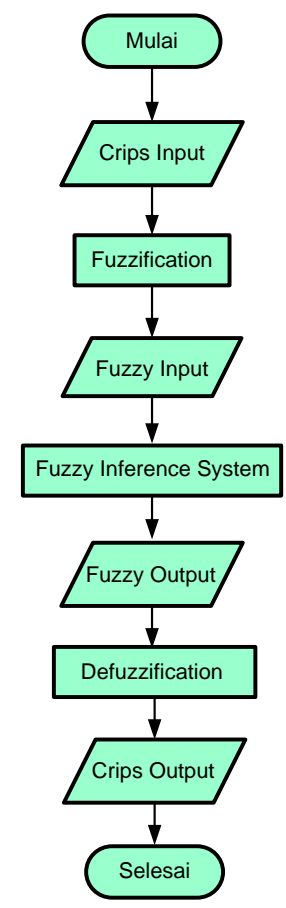

Gambar 2. Diagram Alir Metode Logika Fuzzy

\section{Fuzzy Mamdani}

Gambar 3 menunjukkan blok diagram metoda logika fuzzy. Metode ini mempunyai beberapa tahapan yaitu fuzzifikasi, inferensi fuzzy atau fuzzy inference system (FIS), fuzzy rule base, dan defuzzifikasi. Fuzzifikasi didefinisikan sebagai pemetaan dari himpunan tegas ke himpunan fuzzy (Wang, 1997). Kriteria yang harus dipenuhi pada proses fuzzifikasi adalah semua anggota pada himpunan tegas harus termuat dalam himpunan fuzzy, tidak terdapat gangguan pada masukan sistem fuzzy yang digunakan harus bisa mempermudah perhitungan pada sistem fuzzy. Fuzzy rules base atau aturan fuzzy yang digunakan pada himpunan fuzzy adalah aturan if-then. Secara sederhana aturan fuzzy didefinisikan dalam Persamaan 1 (Sri Kusumadewi et al., 2010).

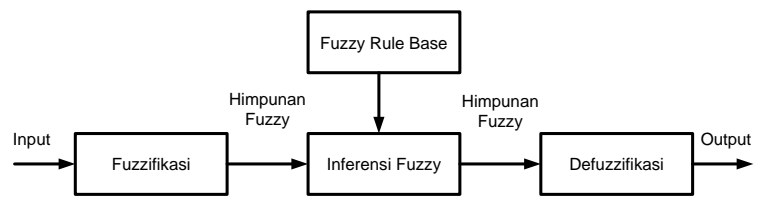

Gambar 3. Blok Diagram Metoda Logika Fuzzy

$$
\text { IF } x_{1} \text { is } A_{2}^{k} \ldots \text {. THEN } y^{k} \text { is } B^{k} \text {.....(1) }
$$

Untuk $k=1,2, \ldots, n, A_{1}^{k}$ dan $A_{2}^{k} \quad$ menyatakan himpunan fuzzy pasangan anteseden ke- $k$, dan $B^{k}$ adalah himpunan fuzzy konsekuen ke-k. Inferensi fuzzy merupakan tahap evaluasi pada aturan fuzzy. Tahap evaluasi dilakukan berdasarkan penalaran 
dengan menggunakan masukan fuzzy dan aturan fuzzy sehingga diperoleh keluaran berupa himpunan fuzzy. Salah satu metode inferensi fuzzy adalah fuzzy mamdani. Metode ini merupakan metode yang paling sederhana dan paling sering digunakan untuk penelitian dibandingkan metode yang lain. Masukan dan keluaran pada metode mamdani berupa himpunan fuzzy. Metode Mamdani menggunakan fungsi implikasi min dan agregasi max sehingga metode Mamdani juga disebut dengan metode MIN-MAX (min-max inferencing). Keluaran untuk aturan metode Mamdani didefinisikan sebagai dalam Persamaan 2 sebagai berikut (Sri Kusumadewi, et. al, 2010).

$$
\mu_{B^{k}}(y)=\max \left[\min \left[\mu A_{1}^{k}\left(x_{i}\right), \mu A_{2}^{k}\left(x_{j}\right)\right]\right]_{k}
$$

untuk $\quad k=1,2, \ldots, n, A_{1}^{k}$ dan $A_{2}^{k}$ menyatakan himpunan fuzzy pasangan anteseden ke- $k$, dan $B^{k}$ adalah himpunan fuzzy konsekuen ke-k. Setelah tahap inferensi fuzzy menggunakan fuzzy rule base, tahap selanjutnya adalah proses defuzzifikasi. Fase ini adalah suatu himpunan fuzzy yang diperoleh dari komposisi aturan-aturan fuzzy, sedangkan keluaran yang dihasilkan merupakan suatu bilangan pada domain himpunan fuzzy tersebut. Sehingga jika diberikan suatu himpunan fuzzy dalam range tertentu, maka akan dihasilkan keluaran berupa crisp dalam nilai tertentu juga tertentu.

\section{Variabel Masukan dan Keluaran}

Penelitian menggunakan tiga fungsi variabel pada masing-masing variabel masukan dan keluaran. Variabel masukan berupa arus beban penyulang masing-masing pada phasa $R$, phasa $S$, dan phasa T. Sedangkan variabel masukan juga berupa berupa arus beban penyulang hasil proses fuzzy mamdani masing-masing pada phasa $R$, phasa $S$, dan phasa $T$. Variabel masukan phasa $R$, phasa $S$, phasa $T$ masing-masing terdiri dari 8 himpunan fuzzy, yaitu: beban sangat kurang, beban kurang, beban sedang, beban normal, kelebihan beban, kelebihan beban sedang, kelebihan beban banyak, dan kelebihan beban sangat banyak. Variabel keluaran phasa $R$, phasa $S$, dan phasa $T$ masing-masing termenjadi 8 himpunan fuzzy, yaitu : pengurangan sangat banyak, pengurangan banyak, pengurangan menengah, pengurangan sedikit, penambahan, penambahan menengah, penambahan banyak, penambahan sangat banyak. Tabel 1 dan Tabel 2 masing-masing menunjukkan fungsi lingustik dan batas himpunan fuzzy mamdani masing-masing untuk variabel masukan dan keluaran.

Tabel 1. Fungsi Lingustik dan Batas Himpunan Fuzzy Mamdani Variabel Masukan R, S, dan T

\begin{tabular}{clcc}
\hline No. & Variable Masukan & $\begin{array}{c}\text { Fungsi } \\
\text { Linguistik }\end{array}$ & Batas \\
\hline 1 & Beban Sangat Kurang & BSK & $0 \mathrm{sd} \mathrm{50}$ \\
2 & Beban Kurang & BK & $35 \mathrm{sd} 85$ \\
3 & Beban Sedang & BS & $65 \mathrm{sd} \mathrm{115}$ \\
4 & Beban Normal & BN & $100 \mathrm{sd}$ \\
& & & 150 \\
5 & Kelebihan Beban & KB & $125 \mathrm{sd}$ \\
6 & Kelebihan Beban & KBS & 175 \\
& Sedang & & $200 \mathrm{sd} 215$ \\
7 & Kelebihan Beban Banyak & KBB & 250 \\
\multirow{2}{*}{8} & Kelebihan Beban Sangat & KBSB & $235 \mathrm{sd}$ \\
& Banyak & & 300 \\
\hline
\end{tabular}

Tabel 2. Fungsi Lingustik dan Batas Himpunan Fuzzy Mamdani Variabel Keluaran R, S, dan T

\begin{tabular}{|c|c|c|c|}
\hline No. & Variable Keluaran & $\begin{array}{c}\text { Fungsi } \\
\text { Linguistik }\end{array}$ & Batas \\
\hline 1 & $\begin{array}{l}\text { Pengurangan Sangat } \\
\text { Banyak }\end{array}$ & PSB & $\begin{array}{c}-150 \mathrm{sd}- \\
85\end{array}$ \\
\hline 2 & Pengurangan Banyak & PB & $\begin{array}{l}-100 \mathrm{sd}- \\
50\end{array}$ \\
\hline 3 & $\begin{array}{l}\text { Pengurangan } \\
\text { Menengah }\end{array}$ & PM & $-65 s d-15$ \\
\hline 4 & Pengurangan Sedikit & PS & -50 sd 25 \\
\hline 5 & Penambahan Normal & PnbN & 0 sd 50 \\
\hline 6 & Penambahan Menengah & PnbM & 35 sd 85 \\
\hline 7 & Penambahan Banyak & PnbB & 65 sd 115 \\
\hline 8 & $\begin{array}{l}\text { Penambahan Sangat } \\
\text { Banyak }\end{array}$ & PnbSB & $\begin{array}{c}100 \text { sd } \\
150\end{array}$ \\
\hline
\end{tabular}

Gambar 4 menunjukkan model FIS dengan tiga masukan dan tiga keluaran arus beban. Gambar 5 dan Gambar 6 masing-masing menunjukkan fungsi keanggotaan variabel masukan dan keluaran arus beban phasa $R$, phasa $S$, dan phasa $T$.

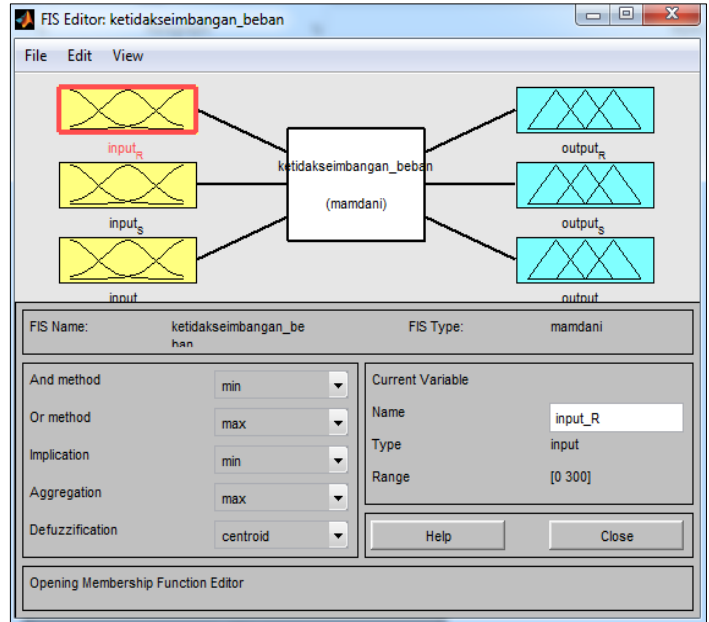

Gambar 4. Model Fuzzy Inference System 

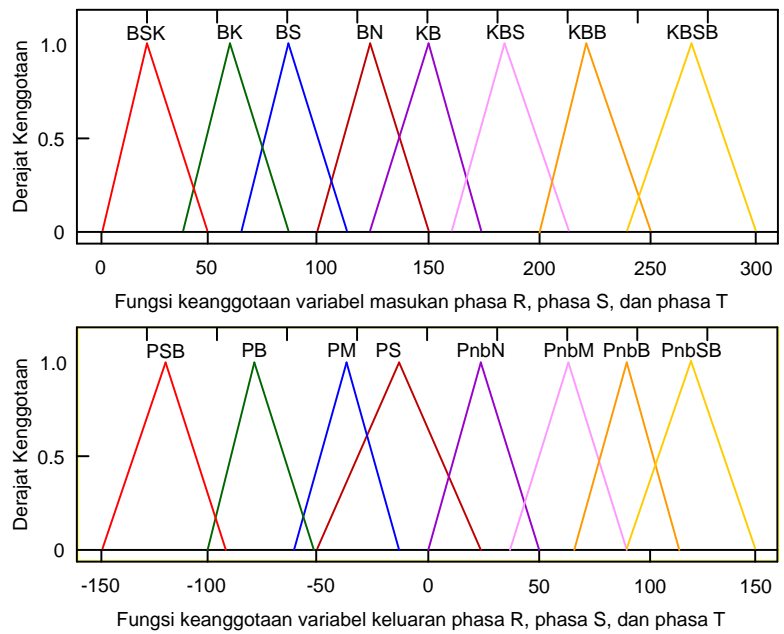

Gambar 5. Fungsi Keanggotaan Variabel Keluaran Arus Beban

\section{Metode Menyeimbangkan Arus Beban}

Penyulang distribusi biasanya berjumlah tiga phasa dan empat kabel dengan sistem dengan struktur radial atau loop terbuka. Untuk mengatasi tegangan dan arus tidakseimbang, maka koneksi antara penyulang khusus dan traformator distribusi harus diatur dengan tepat. Karena beban domestik atau perumahan umumnya terhubung dalam satu phasa. Gambar 1 menunjukkan 150 penyulang saluran distribusi masing-masing mempunyai sakelar selektor yang terhubung ke salah satu phasa pada sistem tiga phasa (Siti et al., 2007).

Penggunaan listrik utama adalah untuk penerangan dan peralatan rumah tangga. Namun, peningkatan daya secara tiba-tiba, seperti penggunaan pemanas, pompa, dan beban berkapasitas besar secara mendadak, sering menyerap daya yang tidak dikehendaki dalam sistem distribusi sistem. Dampak tersebut antaralain: transformator meledak, kabel phasa terbakar, dan ketidakseimbangan beban jaringan. Untuk menyeimbangkan jaringan, teknisi harus mengubah phasa secara manual setelah beberapa pengukuran lapangan. Dalam perumusan umum tentang masalah keseimbangan phasa, status beban tergantung pada variabel independen, sedangkan status sakelar adalah variabel pengoptimalan. Tujuannya supaya dapat dipenuhi performansi strategi kontrol dimana status setiap sakelar pemutus tergantung pada total beban dari setiap penyulang. Dengan strategi tersebut, jaringan bisa lebih optimal dioperasikan dan tidak perlu mengetahui beban terlebih dahulu.

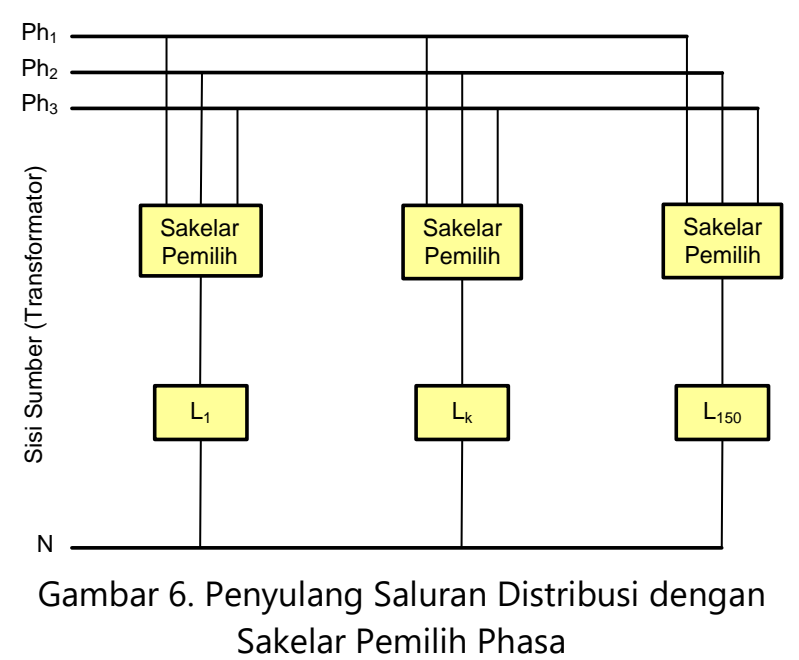

Metode Fuzzy dengan FIS Mamdani digunakan untuk menyeimbangkan arus beban dengan bantuan perangkat lunak Matlab berdasarkan arus masukan pada phasa $R$, phasa $S$, dan phasa $T$. Proses fuzzy mamdani selanjutnya menghasilkan matriks perubahan arus beban yang dinyatakan berdasarkan Persamaan 3 (Siti et al., 2007).

$$
\Delta I_{\text {Fuzzy_Mamdani }}=\left[\begin{array}{l}
\Delta I_{R} \\
\Delta I_{S} \\
\Delta I_{T}
\end{array}\right]
$$

Selanjutnya koreksi nilai kesalahan (error) harus dilakukan sehingga diperoleh nilai average error atau error rata-rata (AE) sesuai dengan Persamaan 4 (Siti et al., 2007).

$$
\begin{gathered}
A E=\frac{\sum \Delta I_{F u z z y \_ \text {Mamdani }}}{3} \\
A E=\frac{\left(\Delta I_{R}+\Delta I_{S}+\Delta I_{T}\right)}{3} \ldots \ldots \ldots . . .(4)
\end{gathered}
$$

Nilai error rata-rata selanjutnya digunakan untuk menyusun matriks error, dengan mendistribusikan nilai $A E$ secara merata diantara tiga phasa dan dinyatakan dalam Persamaan 5 (Siti et al., 2007).

$$
\Delta I_{\text {Error }}=\left[\begin{array}{c}
A E \\
A E \\
\Sigma \Delta I_{\text {Fuzzy_Mamdani }}-2 . A E
\end{array}\right] \ldots
$$

Konfigurasi perubahan beban $(\Delta I)$, diperoleh dengan mengurangi nilai matriks error $\left(\Delta I_{E r r o r}\right)$ dari nilai matriks fuzzy output yang tidak dikoreksi $\left(\Delta I_{\text {Fuzzy_Mamdani }}\right)$ dan dinyatakan Persamaan 6.

$$
\Delta I=\Delta I_{\text {Fuzzy_Mamdani }}-\Delta I_{\text {Error }} \text {...... }
$$

Nilai penjumlahan total perubahan beban $\Delta I$ dinyatakan dalam Persamaan 7 (Siti et al., 2007). 


$$
\sum \Delta I=0
$$

Akhirnya nilai arus pada masing-masing phasa setelah diseimbangkan dinyatakan berdasarkan Persamaan 8 (Siti et al., 2007).

$$
I_{\text {Final }}=I_{\text {Input }}+\Delta I \text {....... }
$$

Setelah nilai arus phasa diperoleh, selanjutnya analisis ketidakseimbangan arus beban ditentukan melalui nilai arus rata-rata berdasarkan Persamaan 9 (Sudiartha et al., 2016).

$$
I_{\text {rata-rata }}=\frac{I_{R}+I_{S}+I_{T}}{3} \ldots
$$

Dimana besarnya arus phasa dalam keadaan seimbang sama dengan besarnya arus rata-rata, maka koefisien $a, b$, dan $c$ diperoleh dengan Persamaan 10.

$$
a=\frac{I_{R}}{I} \quad ; \quad b=\frac{I_{S}}{I} \quad: \quad c=\frac{I_{R}}{I} \ldots . .(10)
$$

Pada keadaan seimbang, besarnya koefisien $a, b$, dan $\mathrm{c}$ adalah 1. Dengan demikian nilai rata-rata ketidakseimbangan arus beban (dalam \%), akhirnya diperoleh dan dinyatakan dalam Persamaan 11 (Sudiartha, et. al, 2016).

$I_{\text {rata-rata ketidakseimbangan }}(\%)=\frac{\{|a-1|+|b-1|+|c-1|\}}{3} \times$

$$
100 \% \text {......(11) }
$$

\section{HASIL DAN PEMBAHASAN \\ Konfigurasi Jaringan Distribusi}

Konfigurasi jaringan distribusi PT. PLN (Persero) UP3 Surabaya Barat Rayon Taman Sidoarjo JawaTimur dijelaskan pada Gambar 7. Penyulang 20 kV berfungsi untuk menghubungkan gardu induk 150/20 kV dengan gardu-gardu tegangan distribusi tegangan rendah (transformator $20 \mathrm{kV} / 380 \mathrm{~V}$ ). Pada penelitian ini selanjutnya dipilih tujuh penyulang 20 kV Area UP3 Taman yang mempunyai nilai ketidakseimbangan arus beban lebih dari $20 \%$. Penyulang-penyulang tersebut antara-lain Tawang Sari, Ngelom, Geluran, Bringin, Masangan Kulon, Palm Residence, dan Pasar Sepanjang. Pengukuran arus beban per-penyulang dilakukan pada waktu beban puncak (WBP) antara pukul 17.00-22.00 WIB.

\begin{tabular}{|c|c|c|c|c|c|}
\hline \multirow{2}{*}{ No } & \multirow{2}{*}{ Penyulang } & \multicolumn{3}{|c|}{$\begin{array}{c}\text { Arus Beban } \\
\text { Masukan (A) }\end{array}$} & \multirow{2}{*}{$\begin{array}{c}\text { Arus Tidak } \\
\text { Seimbang } \\
(\%)\end{array}$} \\
\hline & & $\begin{array}{c}\mathrm{Ph} \\
\mathrm{R}\end{array}$ & $\begin{array}{c}\mathrm{Ph} \\
\mathrm{S}\end{array}$ & $\mathrm{Ph} \mathrm{T}$ & \\
\hline 1 & Ngelom & 235 & 121 & 213 & 24 \\
\hline 2 & Tawang Sari & 253 & 171 & 134 & 24 \\
\hline 3 & Geluran & 299 & 136 & 213 & 26 \\
\hline 4 & $\begin{array}{l}\text { Masangan } \\
\text { Kulon }\end{array}$ & 276 & 136 & 223 & 23.6 \\
\hline
\end{tabular}
Data-data hasil pengukuran arus per-phasa pada tujuh penyulang selanjutnya disajikan pada Tabel 3. Tabel 3. Hasil Pengukuran Arus Beban PLN Rayon Taman

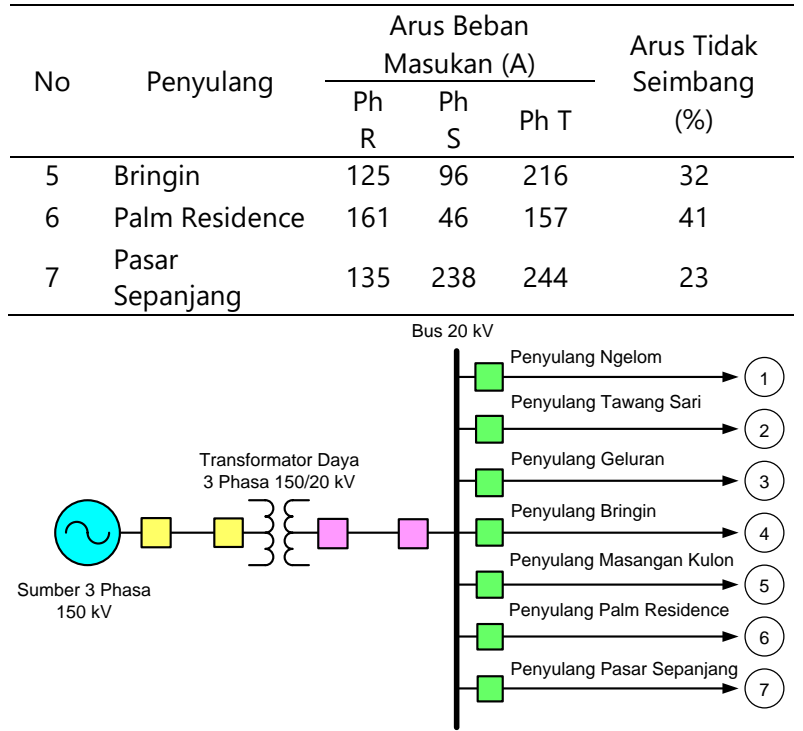

Gambar 7. Konfigurasi Jaringan Distribusi PT. PLN Rayon Taman Sidoarjo

\section{Penentuan Variabel Keluaran dengan Metode Fuzzy Mamdani}

Data-data hasil pengukuran arus beban pada phasa $R$, phasa $S$, dan phasa $T$ sebagaimana ditunjukkan pada Tabel 4 selanjutnya menjadi variabel masukan bagi Metode Logika Fuzzy dengan FIS-Mamdani, sehingga dihasilkan variabel perubahan arus keluaran beban juga pada phasa $R$, phasa S, dan phasa T. Gambar 8 menunjukkan penentuan perubahan arus beban keluaran pada phasa $R$, phasa $S$, dan phasa $T$ pada Penyulang Ngelom.

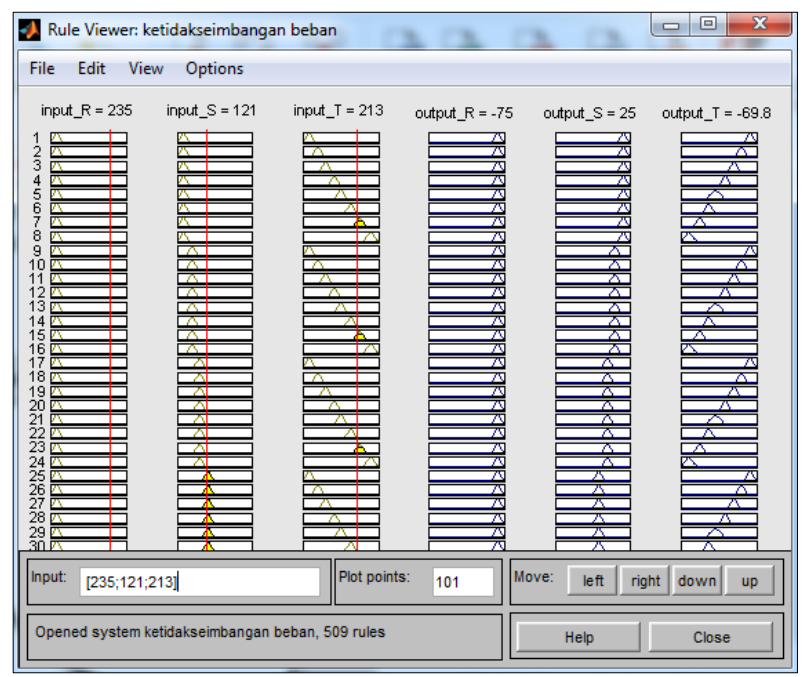

Gambar 8. Penentuan Perubahan Arus Beban Keluaran Pada Phasa R, Phasa S, dan Phasa T

Gambar 8 menunjukkan bahwa pada Penyulang Ngelom dengan variabel masukan masukan phasa $R$, phasa $S$, dan phasa T masing masing sebesar 235 
A, 121 A, dan 213 A, aturan fuzzy pada FIS Mamdani mampu menghasilkan perubahan arus beban keluaran masing-masing phasa sebesar - $75 \mathrm{~A}, 25 \mathrm{~A}$, dan -69 A. Selanjutnya, dengan menggunakan metode sama, maka perubahan arus beban keluaran masing-masing phasa pada enam penyulang lain ditentukan dan hasilnya ditunjukkan pada Tabel 4.

Tabel 4. Perubahan Arus Beban Keluaran

\begin{tabular}{lllccccc}
\hline \multirow{2}{*}{ No. } & \multirow{2}{*}{ Penyulang } & \multicolumn{3}{c}{ Arus Beban Masukan (A) } & \multicolumn{4}{c}{ Perubahan Arus Beban Ouput (A) } \\
\cline { 3 - 8 } & & Ph R & Ph S & Ph T & Ph R & Ph S & Ph T \\
\hline 1 & Ngelom & 235 & 121 & 213 & -75 & 25 & -69.8 \\
2 & Tawang Sari & 253 & 171 & 134 & -117 & -22.6 & 0.73 \\
3 & Geluran & 299 & 136 & 213 & -117 & 1.31 & -58.5 \\
4 & Masangan Kulon & 276 & 136 & 223 & -117 & 3.61 & -75 \\
5 & Bringin & 125 & 96 & 216 & 25 & 60 & -75 \\
6 & Palm Residence & 161 & 46 & 157 & -12.5 & 99.9 & -12.5 \\
7 & Pasar Sepanjang & 135 & 238 & 244 & 0.824 & -88.4 & -101 \\
\hline
\end{tabular}

\section{Penyeimbangan Arus Beban Keluaran dengan Metode Fuzzy Mamdani}

Dengan menggunakan Persamaan 3, selanjutnya diperoleh matriks perubahan arus beban keluaran pada Penyulang Ngelom sebagai berikut:

$$
\Delta I_{\text {Fuzzy_Mamdani }}=\left[\begin{array}{l}
\Delta I_{R} \\
\Delta I_{S} \\
\Delta I_{T}
\end{array}\right]=\left[\begin{array}{c}
-75 \\
25 \\
-69.8
\end{array}\right]
$$

Selanjutnya dengan menggunakan Persamaan 4 maka diperoleh nilai error rata-rata $(A E)$ sebagai berikut :

$A E=\frac{\left(\Delta I_{R}+\Delta I_{S}+\Delta I_{T}\right)}{3}=\frac{((-75)+(25)+(-69.8))}{3}=-39.3$

Berdasarkan nilai $A E$ yang diperoleh, maka nilai matriks error selanjutnya dinyatakan dalam Persamaan 5.

$$
\begin{aligned}
\Delta I_{\text {Error }} & =\left[\begin{array}{c}
A E \\
A E \\
\Sigma \Delta I_{\text {Fuzzy_Mamdani }}-2 . A E
\end{array}\right] \\
\Delta I_{\text {Error }} & =\left[\begin{array}{c}
-39.93 \\
-39.93 \\
-119.8-2 .(-39.93)
\end{array}\right]=\left[\begin{array}{l}
-39.93 \\
-39.93 \\
-39.94
\end{array}\right]
\end{aligned}
$$

Berdasarkan nilai matriks error $\left(\Delta I_{\text {Error }}\right)$ dan nilai matriks fuzzy keluaran yang tidak dikoreksi $\left(\Delta I_{\text {Fuzzy_Mamdani }}\right)$, maka diperoleh nilai konfigurasi perubahan beban $(\Delta I)$ sesuai Persamaan 6 .

$$
\begin{gathered}
\Delta I=\Delta I_{\text {Fuzzy_Mamdani }}-\Delta I_{\text {Error }} \\
A E \\
\Delta I=\left[\begin{array}{l}
\Delta I_{R} \\
\Delta I_{S} \\
\Delta I_{T}
\end{array}\right]-\left[\begin{array}{c}
A E \\
\Sigma \Delta I_{\text {Fuzzy_Mamdani }}-2 . A E
\end{array}\right] \\
\Delta I=\left[\begin{array}{c}
-75 \\
25 \\
-69.8
\end{array}\right]-\left[\begin{array}{l}
-39.93 \\
-39.93 \\
-39.94
\end{array}\right]=\left[\begin{array}{c}
-35.07 \\
64.93 \\
-29.86
\end{array}\right]
\end{gathered}
$$

Akhirnya diperoleh nilai arus keluaran beban pada masing-masing phasa setelah diseimbangkan sesuai Persamaan 8.

$$
\begin{gathered}
I_{\text {Final }}=I_{\text {Input }}+\Delta I \\
I_{\text {Final }}=\left[\begin{array}{c}
235 \\
121 \\
213
\end{array}\right]+\left[\begin{array}{c}
-35.07 \\
64.93 \\
-29.86
\end{array}\right]=\left[\begin{array}{l}
199.93 \\
185.93 \\
183.14
\end{array}\right] \approx\left[\begin{array}{c}
200 \\
186 \\
183
\end{array}\right] A
\end{gathered}
$$

Dengan demikian maka nilai arus beban pada phasa $R$, phasa $S$, dan phasa T pada Penyulang Ngelom, setelah diseimbangkan menggunakan Metode

\begin{tabular}{|c|c|c|c|c|c|c|c|}
\hline \multirow[t]{2}{*}{ No. } & \multirow[t]{2}{*}{ Penyulang } & \multicolumn{3}{|c|}{$\begin{array}{c}\text { Sebelum } \\
\text { Fuzzy Mamdani }\end{array}$} & \multicolumn{3}{|c|}{$\begin{array}{c}\text { Sesudah } \\
\text { Fuzzy Mamdani } \\
\end{array}$} \\
\hline & & $\mathrm{Ph} \mathbf{R}$ & $\mathrm{PhS}$ & $\mathrm{Ph} \mathrm{T}$ & $\mathrm{Ph}$ R & $\mathrm{PhS}$ & $\mathrm{Ph} \mathrm{T}$ \\
\hline 1 & Ngelom & 235 & 121 & 213 & 200 & 186 & 183 \\
\hline 2 & Tawangsari & 253 & 171 & 134 & 182 & 194 & 181 \\
\hline 3 & Geluran & 299 & 136 & 213 & 240 & 195 & 212 \\
\hline 4 & Masangan Kulon & 276 & 136 & 223 & 221 & 202 & 210 \\
\hline 5 & Bringin & 125 & 96 & 216 & 146 & 152 & 137 \\
\hline 6 & Palm Residence & 161 & 46 & 157 & 123 & 121 & 119 \\
\hline 7 & Pasar Sepanjang & 135 & 238 & 244 & 198 & 212 & 205 \\
\hline
\end{tabular}
Fuzzy Mamdani, masing-masing adalah 200 A, 186 A, dan 183 A. Dengan menggunakan metode dan prosedur yang sama, maka nilai arus beban masingmasing phasa pada enam penyulang lainnya disajikan pada Tabel 5.

Tabel 5. Nilai Arus Beban Sebelum dan Setelah Phasa Diseimbangkan

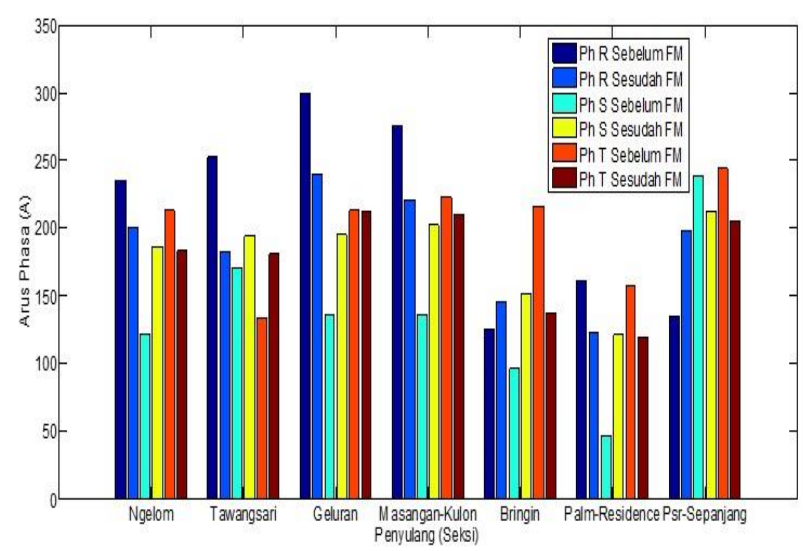

Gambar 9. Perbandingan Nilai Arus Beban Pada Phasa R, Phasa S, dan Phasa T

Tabel 5 dan Gambar 9 menunjukkan bahwa sebelum Metode Fuzzy Mamdani diterapkan, Penyulang Geluran phasa R menghasilkan arus beban paling tinggi sebesar 299 A. Penyulang Palm Residence phasa $\mathrm{S}$ menghasilkan arus beban paling rendah sebesar 46 A. Implementasi Metode Fuzzy Mamdani pada jaringan distribusi yang diusulkan menghasilkan bahwa Penyulang Geluran phasa $R$ menghasilkan arus beban paling tinggi sebesar 240 A. Penyulang Palm Residence phasa T menghasilkan arus beban paling rendah sebesar $119 \mathrm{~A}$. 


\section{Ketidakseimbangan Arus Beban Menggunakan Metode Fuzzy Mamdani}

Pada Penyulang Ngelom, dengan menggunakan persamaan 9, Tabel 6, dan Gambar 9, maka diperoleh nilai arus rata-rata sebagai berikut:

$I_{R}=200 \quad ; I_{S}=186 \quad ; I_{T}=183$, maka

$I_{\text {rata-rata }}=\frac{I_{R}+I_{S}+I_{T}}{3}=\frac{200+186+183}{3}=189$

Koefisien a, b, dan $c$, selanjutnya diperoleh menggunakan Persamaan 10 sebagai berikut:

$a=\frac{I_{R}}{I}=\frac{200}{189}=1.05 \quad ; \quad b=\frac{I_{S}}{I}=\frac{186}{189}=$

$0.98 ; c=\frac{I_{R}}{I}=\frac{183}{189}=0.96$

Akhirnya nilai rata-rata ketidakseimbangan arus beban diperoleh menggunakan Persamaan 11 sebagai berikut :

$I_{\text {rata-rata ketidakseimbangan }}(\%)=\frac{\{|a-1|+|b-1|+|c-1|\}}{3} \times$

$100 \%=\frac{\{|1.05-1|+|0.98-1|+|0.96-1|\}}{3} \times 100 \%=3.6 \%$

Tabel 6. Nilai Ketidakseimbangan Arus Beban

\begin{tabular}{|c|l|c|c|}
\hline \multirow{2}{*}{ No } & Penyulang & \multicolumn{2}{|c|}{$\begin{array}{c}\text { Ketidakseimbangan arus } \\
\text { beban }\end{array}$} \\
\cline { 3 - 4 } & & $\begin{array}{c}\text { Sebelum } \\
\text { Fuzzy } \\
\text { Mamdani } \\
\text { (\%) }\end{array}$ & $\begin{array}{c}\text { Sesudah } \\
\text { Fuzzy } \\
\text { Mamdani } \\
\text { (\%) }\end{array}$ \\
\hline 1 & Tawang Sari & 24 & 3.6 \\
\hline 2 & Ngelom & 24 & 3 \\
\hline 3 & Geluran & 26 & 7.6 \\
\hline 4 & Masangan & 23.6 & 3.6 \\
\hline 5 & Kulon & 32 & 4 \\
\hline 6 & Palm Residence & 41 & 1.6 \\
\hline 7 & Pasar Sepanjang & 23 & 2 \\
\hline
\end{tabular}

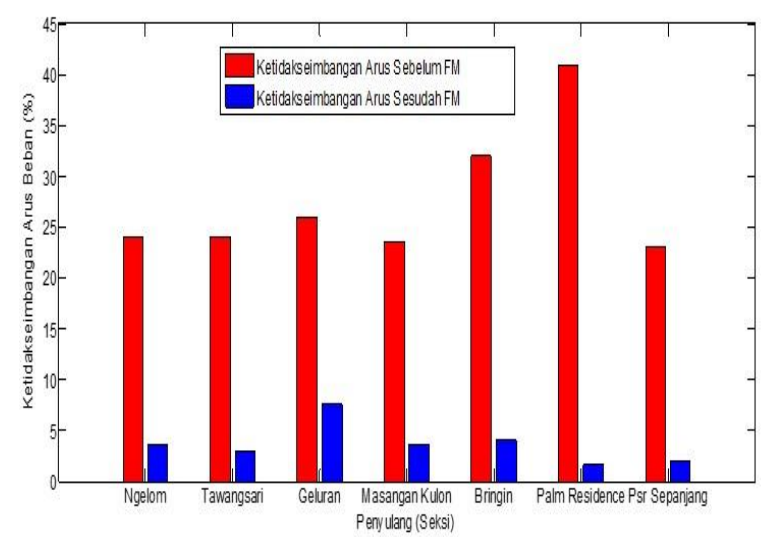

Gambar 10. Perbandingan Nilai Rata-Rata Ketidakseimbangan Arus Beban

Gambar 10 menunjukkan perbandingan nilai rata-rata ketidakseimbangan arus beban pada tujuh penyulang sebelum dan sesudah menggunakan
Metode Fuzzy Mamdani. Maka nilai rata-rata ketidakseimbangan arus beban pada Penyulang Ngelom, menggunakan Metode Fuzzy Mamdani adalah $3.6 \%$. Dengan menggunakan metode dan prosedur yang sama, nilai rata-rata ketidakseimbangan arus beban pada enam penyulang lainnya. Gambar 10 menunjukkan bahwa sebelum Metode Fuzzy Mamdani, Penyulang Palm Residence menghasilkan nilai ketidakseimbangan arus beban paling tinggi sebesar $41 \%$. Penyulang Pasar Sepanjang menghasilkan nilai ketidakseimbangan arus beban paling rendah sebesar 23\%. Implementasi Metode Fuzzy Mamdani menghasilkan bahwa Penyulang Geluran menghasilkan nilai ketidakseimbangan arus beban paling tinggi sebesar $7.6 \%$. Penyulang Palm Residence menghasilkan nilai ketidakseimbangan arus beban paling rendah sebesar $1.6 \%$. Hasil ini menunjukkan bahwa Metode Logika Fuzzy dengan FIS Mamdani mampu menurunkan nilai arus beban tidak seimbang secara signifikan jauh dibawah Standar Standar PLN Nomor 1 Tahun 1995 maksimal sebesar $20 \%$.

Perbandingan metode fuzzy mamdani dengan penambahan nominal aturan fuzzy dalam analisis keseimbangan beban (usulan penelitian) terhadap penelitian sebelumnya ditunjukkan pada Tabel 8. Metode logika fuzzy dengan FIS Mandani untuk analisis keseimbangan beban penyulang PLN Rayon Kuta Bali sudah diusulkan oleh (Suryawan et al., 2018). Variabel masukan berjumlah 3 masingmasing arus beban pada phasa $R$, phasa $S$, dan phasa T. Sedangkan variabel keluaran berjumlah 3 masing-masing perubahan arus beban pada phasa $R$, phasa $S$, dan phasa $T$. Dengan aturan fuzzy berjumlah 27 rules, implementasi metode ini mampu menghasilkan nilai ketidakseimbangan arus beban terkecil sebesar $1.9 \%$.

Metode logika fuzzy untuk menyeimbangkan beban dengan FIS Mandani juga sudah diusulkan oleh (Kahfi et al., 2017). Variabel masukan fuzzy yang berjumlah 3 meliputi tegangan, arus asli, dan arus efisien dengan variabel keluaran berjumlah 1 yaitu prosentase tegangan transformator yang paling efisien. Dengan menggunakan 8 aturan fuzzy, metode ini mampu menentukan urutan kerja transformator secara efisien dengan nilai MAPE sebesar $10,4 \%$, dengan kelemahan tidak mampu menentukan nilai keseimbangan beban. Perangkat lunak berbasis Metode logika fuzzy dengan FIS Tsukamoto dan 9 aturan fuzzy untuk menentukan 
faktor pembebanan dan mendeteksi jenis gangguan pada transformator distribusi PLN sudah diimplementasikan oleh (Thamrin et al., 2012). Deteksi kerusakan transformator pada penelitian ini ditentukan oleh 4 variabel masukan yaitu pembebanan, ketidakseimbangan beban, jatuh tegangan, dan faktor daya transformator serta 1 variabel keluaran yaitu derajat kerusakan transformator.

Metode logika fuzzy dengan FIS Mamdani sebagai evaluasi distribusi daya berdasarkan beban puncak pembangkit sudah diperkenalkan oleh Rosalina et al., (2016). Evaluasi daya pada sistem pembangkit menggunakan 3 variabel masukan antara-lain kapasitas terpasang, kemampuan daya, dan produksi listrik serta data beban puncak sebagai variabel keluaran. Metode logika fuzzy dengan FIS Mamdani dan 8 aturan fuzzy untuk menyeimbangkan beban total per-phasa dalam kilowatt (kW) pada jaringan distribusi sekunder diinvestigasi oleh (Siti et al., 2007). Variabel masukan berjumlah 3 masing-masing arus beban pada phasa $R$, phasa $S$, dan phasa T. Sedangkan variabel keluaran berjumlah 1 yaitu perubahan arus beban, masing-masing phasa $\mathrm{R}$, phasa $\mathrm{S}$, dan phasa T dengan 3 buah blok model FIS Mandani terpisah. Metode mendekati sama juga sudah dilakukan (Saumil Navalbhai Patel, 2009). Pada penelitian ini, penulis mengusulkan metode logika fuzzy dengan FIS Mamdani. Serupa dengan penelitian metode ini menggunakan 3 variabel masukan masing-masing arus beban pada phasa $R$, phasa $S$, dan phasa $T$. Perbedaannya adalah variabel keluaran penelitian berjumlah 3 tetapi tetap berada dalam 1 blok FIS dimana masing-masing adalah perubahan phasa $R$, phasa $\mathrm{S}$, dan phasa T. Dengan konfigurasi seperti ini dibutuhkan jumlah aturan fuzzy yang lebih besar sebanyak 509 rules, namun kelebihannya dibandingkan metode oleh peneliti lainnya, metode yang diusulkan mampu menghasilkan nilai ketidakseimbangan arus beban terendah yaitu 1.6 \%. Dengan demikian pengembangan nominal (jumlah) aturan fuzzy (fuzzy rules) pada metode logika fuzzy dengan FIS Mamdani, mampu menurunkan nilai ketidakseimbangan arus beban penyulang pada saluran distribusi tegangan menengah $20 \mathrm{kV}$.

\section{KESIMPULAN}

Metode logika fuzzy menggunakan FIS Mamdani untuk menyeimbangkan arus beban tiga phasa pada tujuh penyulang distribusi tegangan menengah 20 kV PLN Rayon Taman Jawa-Timur sudah diusulkan. Implementasi Metode Fuzzy Mamdani menghasilkan bahwa Penyulang Geluran menghasilkan nilai ketidakseimbangan arus beban paling tinggi sebesar $7.6 \%$. Penyulang Palm Residence menghasilkan nilai ketidakseimbangan arus beban paling rendah sebesar 1.6\%. Hasil ini menunjukkan bahwa Metode Logika Fuzzy dengan FIS Mamdani mampu menurunkan nilai arus beban tidak seimbang secara signifikan jauh dibawah Standar Standar PLN Nomor 1 Tahun 1995 maksimal sebesar 20\%. Dengan konfigurasi jumlah aturan fuzzy (fuzzy rules) sebanyak 509 rules, metode yang diusulkan mampu menghasilkan nilai ketidakseimbangan arus beban terendah sebesar $1.6 \%$ pada Penyulang Palm Residence. Pengembangan nominal (jumlah) aturan fuzzy pada Metode Logika Fuzzy dengan FIS Mamdani, mampu menurunkan nilai ketidakseimbangan arus beban penyulang pada saluran distribusi tegangan menengah $20 \mathrm{kV}$ lebih baik dibandingkan metode yang diusulkan oleh peneliti sebelumnya. Dengan nominal rules pada variable keluaran yang semakin banyak, maka pengolahan data menggunakan Metode Fuzzy-Mamdani menjadi semakin kompleks dan membutuhkan waktu relatif lama. Metode logika fuzzy menggunakan FIS Sugeno dengan fungsi Singleton yang memiliki derajat keanggotaan 1 dan 0 pada nilai crisp keluaran dapat diusulkan untuk mengatasi kendala tersebut.

\section{DAFTAR PUSTAKA}

I Putu Weda Suryawan, Anak Agung Ngurah Amrita, dan Widyadi Setiawan, (2018), Analisa Penyeimbang Beban Pada Transformator Distribusi Menggunakan Metode Fuzzy, Majalah Ilmiah Teknologi Elektro, Vol. 17, No. 1, JanuariApril 2018, 143-149, DOI: https://doi.org/10.24843/MITE.2018.v17i01.P19.

I Wayan Sudiartha, I Putu Sutawinaya, I Ketut TA, dan Ardy Firman, (2016), Manajemen Trafo Distribusi 20 kV Antar Gardu BL031 Dan BL033 Penyulang Liligundi Dengan Menggunakan Simulasi Program Etap", Jurnal Logic. Vol. 16. No. 3. 166-171, Nopember 2016.

Gassing dan Indra Jaya, (2013), Optimalisasi Pembebanan Transformator Distribusi Dengan Penyeimbangan Beban, Prosiding Hasil Penelitian Fakultas Teknik Universitas 
Hasanuddin Makassar, Volume 7: Desember 2013, Grup Teknik Elektro, TE4-1-TE4-12, ISBN: 978-979-127255-0-6.

Tejo Sukmadi dan Bambang Winadi, (2009), Perhitungan Dan Analisis Keseimbangan Beban Pada Sistem Distribusi 20 kV Terhadap RugiRugi Daya (Studi Kasus Pada PT.PLN UPJ Slawi), Transmisi, Jurnal Teknik Elektro, Jilid 11, Nomor 1, 47-52, Maret 2009.

M. Putra, C. G. I. Partha, dan I. N. Budiastra, (2017), Rancang Bangun Penyeimbangan Arus Beban Pada Sistem Tiga Fasa Menggunakan Mikrokontroller Atmega 2560, Teknologi Elektro, Vol. 16, No1, 21-29, Januari-April 2017.

Nazaruddin, Mahalla, dan Fauzi, (2019), GaussSeidel Method For Calculation of Unbalance Load Flow, International Conference on Science and Innovated Engineering (I-COSINE), IOP Conf. Series: Materials Science and Engineering 536, 012054, 1-9, doi:10.1088/1757$899 \times / 536 / 1 / 012054$.

Syarif Hidayat, Supridi Legino, dan Nurun Fatihah Mulyanti, (2018), Penyeimbangan Beban Pada Jaringan Tegangan Rendah Gardu Distribusi CD 33 Penyulang Sawah Di PT. PLN (Persero) Area Bintaro, Jurnal Sutet, Vol. 8 No.1, 21-27, Januari Juni 2018.

Juliana Sitepu, (2011), Studi Pengaruh Ketidakseimbangan Beban Terhadap Arus Netral Dan Losses Pada Trafo Distribusi PLN Ranting Lubuk Pakam, Tugas-Akhir, Program Studi Teknik Elektro, Fakultas Teknik, 1-59, Universitas Sumatra Utara.

Putu Arya Mertasana, (2016), Pengaruh Ketidakseimbangan Beban Terhadap Arus Netral Dan Losses Pada Transformator Distribusi KA 0562 Pada Pentulang Uma Alas Mengwi Badung, Laporan Penelitian, Program Studi Teknik Elektro Dan Komputer, Fakultas Teknik, 1-34, Universitas Udayana Bukit Jimbaran.

Dennis Satria Wahyu Jayabadi, Bambang Winardi, dan Mochammad Facta, (2016), Analisa Ketidakseimbangan Beban Trafo $1 \mathrm{Gl}$ Srondol Terhadap Rugi-Rugi Akibat Arus Netral Dan
Suhu Trafo Menggunakan Etap 12.6.0, Transient, Vol.5, No. 4, 1-7, Desember 2016, ISSN: 23029927, 426.

Antonov, Doni Aprinaldo, (2015), Optimasi Penyeimbangan Beban Pada Trafo Distribusi Terhadap Susut Energi (AplikasiFeedr Sikakap)," Jurnal Teknik Elektro, Institut Teknologi Padang (ITP), Volume 4 No. 1, 65-70, Januari 2015.

Fazari Abdillah, Margo Pujiantara, dan Soedibjo, (2014), Penyeimbangan Beban Pada Gadrdu Distribusi Dengan Metode Seimbang Beban Seharian Di PT. PLN Area Bukuttinggi, JURNAL TEKNIK POMITS, Vol. 1, No. 1, 1-6, Institut Teknologi Sepuluh November (ITS) Surabaya.

Antonov Bachtiar dan Bayu Dirgantara, (2017), Optimalisasi Penyeimbanagan Beban Transformator Dengan Metode Seimbang Beban Seharian (SBS) Pada Gardu Depan Kantor Rayon PT. PLN (Persero) Rayon Kayu Aro, Jurnal Teknik Elektro, Institut Teknologi Padang (ITP), Vol. 6, No. 1, 112-119, Januari 2017.

Aulia Kahfi dan Agus Maman Abadi, (2017), Aplikasi Logika Fuzzy Pengambilan Keputusan Untuk Efisiensi Kerja Trafo Listrik Di Yogyakarta, Proseding Seminar Matematika dan Pendidikan Matematika, PT-25-PT32, Jurusan Pendidikan Matematika, Universitas Negeri Yogyakarta.

Fanoeel Thamrin, (2012), Studi Inferensi Fuzzy Tsukamoto Untuk Penentuan Faktor Pembebanan Trafo PLN, Tesis, Program Studi Magister Sistem Informasi, Program Pascasarjana, 1-45, Universitas Diponegoro Semarang.

Fifi D. Rosalina, Yuniar Farida, dan Abdulloh Hamid, (2016), Metode Logika Fuzzy Sebagai Evaluasi Distribusi Daya Listrik Berdasarkan Beban Puncak Pembangkit Tenaga Listrik, Jurnal Matematika MANTIK, Edisi: Oktober 2016. Vol. 02 No. 01, 22-29, Universitas Negeri Sunan Ampel Surabaya, ISSN: 2527-3159 dan E-ISSN: 2527-3167.

M.W. Siti, A.A. Jimoh and D.V. Nicolae, (2007), Phase Load Balancing in the Secondary Distribution Network Using Fuzzy Logic, Africa International 
Conference (AFRICON), 1-6, 26-28 Sept. 2007, Windhoek, South Africa, DOI: 10.1109/AFRCON.2007.4401569.

Saumil Navalbhai Patel, (2010), Power Load Balancing Using Fuzzy Logic, Master Theses,
Electrical and Electronic Engineering, California State University, Sacramento.

Sri Kusumadewi dan Hari Purnomo, Aplikasi Logika Fuzzy untuk Pendukung Keputusan, Graha ilmu. Yogyakarta, 2013 